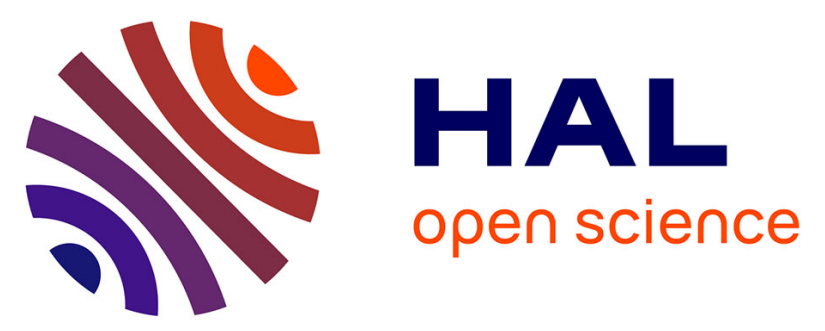

\title{
Attempts to inhibit testicular growth in rainbow trout with antiandrogens (cyproterone, cyproterone acetate, oxymetholone) and busulfan given during the period of spermatogenesis
}

Roland Billard

\section{To cite this version:}

Roland Billard. Attempts to inhibit testicular growth in rainbow trout with antiandrogens (cyproterone, cyproterone acetate, oxymetholone) and busulfan given during the period of spermatogenesis. General and Comparative Endocrinology, 1982, 48 (1), pp.33-38. 10.1016/0016-6480(82)90035-1. hal-02728680

\section{HAL Id: hal-02728680 \\ https://hal.inrae.fr/hal-02728680}

Submitted on 2 Jun 2020

HAL is a multi-disciplinary open access archive for the deposit and dissemination of scientific research documents, whether they are published or not. The documents may come from teaching and research institutions in France or abroad, or from public or private research centers.
L'archive ouverte pluridisciplinaire HAL, est destinée au dépôt et à la diffusion de documents scientifiques de niveau recherche, publiés ou non, émanant des établissements d'enseignement et de recherche français ou étrangers, des laboratoires publics ou privés.

\section{다(1)(2)}

Distributed under a Creative Commons Attribution - ShareAlikel 4.0 International 


\title{
Attempts to Inhibit Testicular Growth in Rainbow Trout with Antiandrogens (Cyproterone, Cyproterone Acetate, Oxymetholone) and Busulfan Given during the Period of Spermatogenesis
}

\author{
R. BILLARD \\ Laboratoire de Physiologie des Poissons, INRA, 78350 Jouy en Josas, France
}

Accepted October 16, 1981

\begin{abstract}
We tried to inhibit spermatogenesis in adult male rainbow trout by giving them a daily diet (1\% of body wt) containing antiandrogens-cyproterone, cyproterone acetate (Schering), oxymetholone (Syntex) -at dose of 20 or $40 \mathrm{mg} / \mathrm{kg}$ in the food, or by injecting an antimitotic agent, busulfan (Misulban, Techni-pharma), at doses of $10 \mathrm{mg} / \mathrm{kg}$ of body weight twice a month for 153 or 162 days, over the main period of testicular activity. When the cyproterone acetate and oxymetholone treatments were started before initiation of spermatogenesis, there was no testicular growth, but when spermatogenesis had already begun in June, the inhibitory effect of these drugs was limited; cyproterone acetate in that case had no effect at all. A limited number of spermatogonia were present in the undeveloped testis, suggesting that the effect could be reversible. GTH secretion was not suppressed, indicating that the drug had a direct effect on the gonads. During the expcriment, body weight increased by $18 \%$ in the control group. In the groups given inhibitory treatments, body weight decreased slightly $(6 \%)$ with cyproterone acetate but was markedly reduced (10\%) after the oxymetholone treatment. Large-scale experimentation is necessary to test the effect of these drugs on growth. In conclusion, it appears that only cyproterone acetate, preventing male sexual maturation, is of interest in fish culture. It may also prove to be a useful tool for laboratory experimentation.
\end{abstract}

Techniques of fish gonad sterilization are useful in both the practice of fish culture and in fish management, for instance, when introducing new species in rivers or lakes. Some methods are based on a genetic approach (Chevassus et al., 1979) while others use steroid administration. The latter technique has been carried out in juveniles at the time of sex differentiation (Jalabert $e t$ al., 1975; Yamazaki, 1976; Johnstone et al., 1978; Goetz et al., 1979) or in adults during gametogenesis (Billard et al., 1981). The use of steroids, however, may face problems of legal limitation, and so other drugs need investigation. The present paper reports the effects of three antiandrogens (cyproterone, cyproterone acetate, and oxymetholone) and one antimitotic agent (busulfan) on testicular development and circulating gonadotropin (t-GTH) in adult rainbow trout males. Antiandrogen has been reported to reversibly inhibit spermatogenesis in mammals (Steinbeck et al., 1971; Morse et al., 1973) and to have behavioral effects on fish (Rouse et al., 1977), as well as inhibitory effects in secondary sex characters (Hamaguchi, 1978). Busulfan, an alkylating substance with antimitotic activity, is reported to sterilize male rats when administered in utero (Hemsworth and Jackson, 1962; Gillet and Laporte, 1973 ) and to limit fertility in adults (Jackson et al., 1959).

\section{MATERIAL AND METHODS}

Our experiments were conducted in 1975 and 1976. Two-year-old rainbow trout males weighing about 200 $\mathrm{g}$ and originating from the Forgeot fish farm were brought to our laboratory in March and kept in recycled water in our experimental facilities. They were still at the running stage and easy to sex. We fed them 
$1 \%$ of their body weight daily in regular fish pellets (Trouw) until the experiment began on June 15, 1975 and on May 10, 1976. At this time some males were killed for removal of gonads and histological determination of the stage of spermatogenesis. Groups of 11 to 15 fish were fed the regular pellets above (controls) or those containing 20 or $40 \mathrm{mg} / \mathrm{kg}$ of an antiandrogen: cyproterone or cyproterone acetate (CA) (Schering AG-D1, Berlin 65, Postfach 650311) or oxymetholone (Syntex, Hillview, Palo Alto, Calif.) (Table 1). The drugs were first dissolved in oil which was mixed with wheat, fishmeal, vitamins, and minerals to make the pellets. These were fed daily at $1 \%$ of body weight. The antimitotic compound, busulfan (Misulban, Techni-pharma, BP 159, Monaco), was injected intraperitoneally at a dose of $10 \mathrm{mg} / \mathrm{kg}$ of body weight/ injection with 2 injections/month. The fish were weighed periodically, and their blood was sampled for trout gonadotropin (t-GTH) (glycoprotein) which was measured by radioimmunoassay in the same manner as for carp (Breton et al., 1971). The experiments ended on November 24, 1976. All the fish were then checked for signs of sperm release and killed after they had been starved for 3 days; the body, gonads and liver were weighed to calculate the gonadosomatic index (GSI) and the hepatosomatic index (HSI). The testes were fixed in Bouin-Hollande and the $7-\mu \mathrm{m}$ sections stained with hematoxylin for histological examination.

Variance analysis was used to statistically compare the results after log transformation for the GSI. Values on figures and table are given $\pm \mathrm{SD}$.

\section{RESULTS}

\section{Gonadal Changes}

During the 1976 experiment, which started in May the testes were still in the resting stage, only type-A spermatogonia $\left(G_{A}\right)$ were found in the lobule with occasional spermatozoon resorption. Cyproterone acetate and oxymetholone entirely prevented gonadal development, and at the end of the treatment the GSI was significantly lower $(P<0.005)$ than in the controls (Table 1). Some isolated $G_{A}$ 's were occasionally present in the undeveloped testis, but no other germ cells were found.

The 1975 experiment started in June after some spermatogenetic activity had began in the testes: type-B spermatogonia $\left(G_{B}\right)$ and some spermatocytes I. Cyproterone had only a limited effect: the gonads in 2 males remained at the resting stage, while 3 males showed signs of spermatogenetic activity and 2 others were fully mature (spermiating). Cyproterone acetate had no effect and all the males were in the running stage. Busulfan had irregular effects: 2 male gonads were still regressed and 4 were in full spermiation.

Histological examination showed that even in the entirely regressed gonad, some $G_{A}$ 's were present. The structure of the testis was altered, however: the lobular structure was hardly visible, the gonadal wall was very thick and there was considerable connective tissue.

\section{GTH Changes}

In the 1975 experiment, the mean GTH level was not much different in the controls and in the cyproterone-treated group but was higher in the cyproterone acetate-treated group (Fig. 1). In cyproterone-treated males which had reached maturity, t-GTH was higher than in males with regressed testis. Plasma GTH level was even higher in the mature cyproterone acetate-treated males than in the mature controls (Fig. 1). It was not altered by the busulfan treatment (Fig. 2).

The results on the 1976 experiment were quite different (Fig. 3): there was no elevation in plasma GTH in the treated fish; the rise observed in the controls toward the end of the experiment occurred later in the cyproterone acetate-treated group and not at all in the fish given oxymetholone.

\section{Changes in Growth}

No treatment side effects were seen to affect the HSI, but the fish lost weight with the oxymetholone treatment (10\%) (Fig. 4). The overall weight gain during the experiment was low in all the other groups, even in the controls (Table 1).

\section{DISCUSSION}

The effects of antiandrogen treatment were not the same in the 1975 and 1976 experiments. One of the major differences 


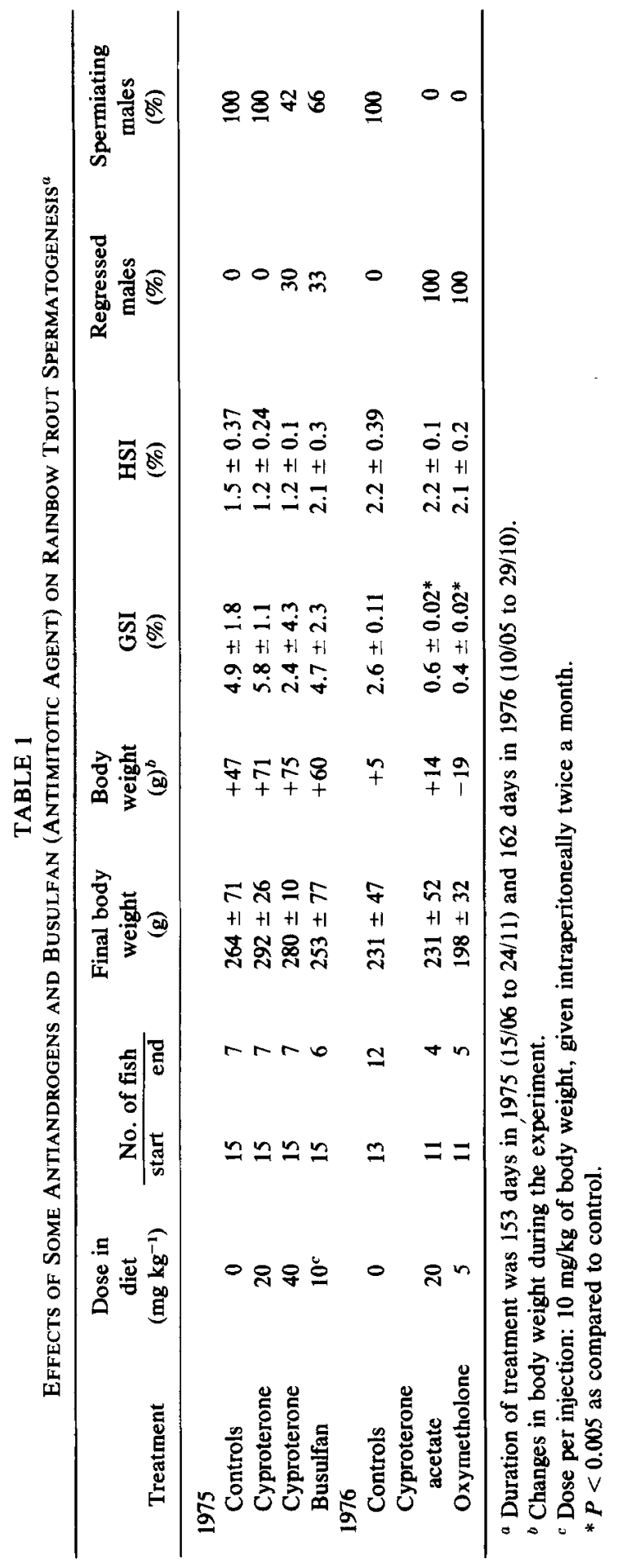




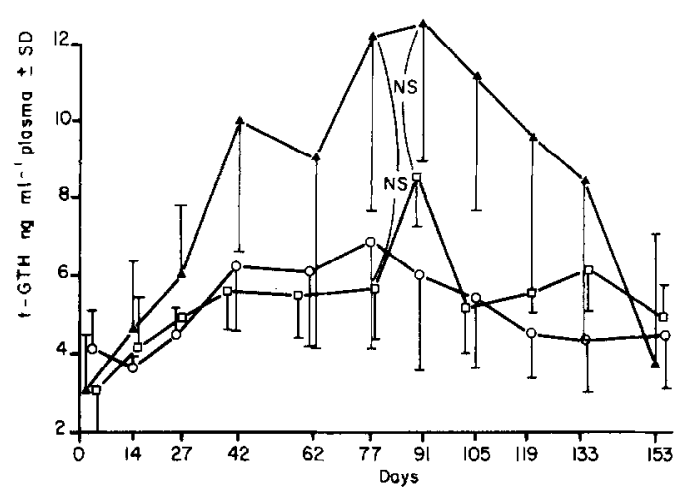

FIG. 1. Changes in immunoreactive $\mathrm{t}-\mathrm{GTH}$ in plasma of male rainbow trout following treatment with cyproterone (Cyp) and cyproterone acetate (CA) added to the diet (respectively, 40 and $20 \mathrm{mg} / \mathrm{kg}$ of pellet). Control males received normal diet. Treatment started on May 10, 1976 when gonads were still in a resting stage (NS, nonsignificant; there was no significant difference between the three groups). $\square$, Control; O, Сур; $\triangle$, CA.

was the stage of spermatogenesis when the treatment started. It therefore seems that testicular development can be inhibited by antiandrogens (cyproterone, cyproterone acetate, and oxymetholone) only when the treatment begins before spermatogenesis has started. After that, the results are heterogeneous and gonadal development is prevented only in a limited number of cases. Murphy (1980) also observed that

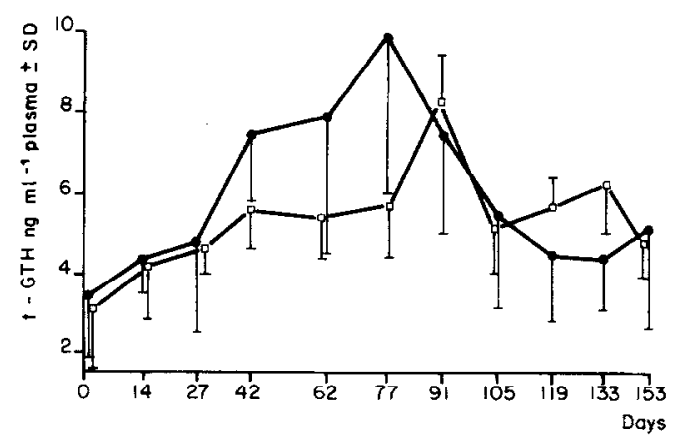

FIG. 2. Changes in t-GTH in plasma of male rainbow trout receiving one intraperitoneal injection twice a month of Busulfan (10 $\mathrm{mg} / \mathrm{kg}$ body wt/injection) during 153 days. Treatment started on May 10, 1976 (Day 0) before spermatogenesis had started. Control group is the same as in Fig. 1. There is no difference between the 2 groups. $\square$, Control; $\odot$, busulfan.

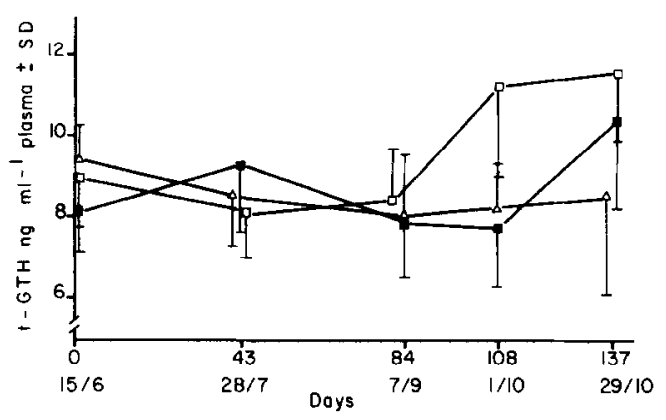

FIG. 3. Changes in immunoreactive $t-G T H$ in plasma of rainbow trout males receiving oxymetholone (OX) and cyproterone acetate (CA) added to the diet (5 and $20 \mathrm{mg} / \mathrm{kg}$ of food, respectively). When the treatment started (15/6/1975) spermatogenesis had already begun. Control group received normal pelleted food. $\square$, Control; $\triangle$, OX; $\mathbf{Q}, \mathrm{CA}$.

cyproterone acetate given to Atlantic salmon parr at the end on spermatogenesis had no effect on testis weight. Rouse et al. (1977), however, reported an inhibition of the formation of spermatids and spermatozoa in stickleback after cyproterone acetate treatment. The subsistance of $\mathrm{G}_{\mathrm{A}}$ 's in the undeveloped testis indicates that the effect of the treatment may be reversible. The consequences of antiandrogenic treatment on circulating t-GTH are not clear. When gonadal development was prevented (1976 experiment), the GTH levels were not significantly different from the controls, suggesting a direct effect on the gonad rather than on the central nervous system. But when the treatment did not prevent testicular development, the mature treated

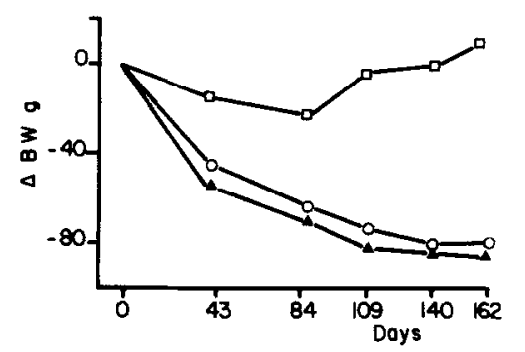

FIg. 4. Changes in body weight (BW) in the oxymetholone (OX) and cyproterone acetate (CA) treated groups (1975 experiment). $\square$, Control; $\boldsymbol{\Delta}$, OX; O, CA. 
males had a higher plasma GTH concentration than the controls at the same stage of maturity. A direct effect on the gonads is also suggested by the results of Schreck (1973) who showed a blockage of the uptake of tritiated testosterone on trout testis by cyproterone acetate and Murphy (1980) who reported a significant decrease of plasma 11 ketotestosterone after cyproterone acetate treatment in salmon parr. Gonadal negative feedback (Billard et al., 1977) at the hypothalamo-pituitary level might be limited by the antiandrogenic action of the drug, as shown in rats by Viguier-Martinez (1976), but a similar action did not occur in the testis since spermatogenesis was normal. In addition, the progestational side effect of cyproterone acetate, which in mammals reduces GTH release (Steinbeck et al., 1971), did not appear in trout, as shown in this experiment. It has already been reported that progestogens tend to stimulate GTH secretion (Billard et al., 1981). The doses of cyproterone and cyproterone acetate used in this experiment were relatively low (about 0.2 and $0.4 \mathrm{mg} / \mathrm{kg}$ of body wt/day); higher doses might have been more efficient in maturing males. In rats, reduction in fertility is related to the dose, and a reduction in testis weight is observed after daily treatment with $20 \mathrm{mg}$ of cyproterone acetate for 5 weeks (Back et al., 1977).

The other antiandrogen, oxymetholone, which was tested only in the 1976 experiments, was as potent as cyproterone acetate in inhibiting gonadal growth but it decreased body weight during the experiment, thus limiting its practical use in fish culture.

The antimitotic agent, busulfan, had only a limited effect: only 2 out of 6 fish were sterilized with the dose used $(0.7 \mathrm{mg} /$ day $)$. This is quite different from the results reported in mammals in which a single dose (about 6 to $16 \mathrm{mg} / \mathrm{kg}$ of body wt) of busulfan or other sulfonic ester induces a noticeable reduction in spermatogenesis by inhibiting mitosis in the spermatogonia or by damag- ing the postmeiotic stages (Gilmore, 1973) in various species: rat (Partington et al., 1964), rabbit (Fox et al., 1963), mouse and hamster (De Rooij and Kramer, 1970). Therefore, this compound is not very promising as an antifertility agent for adult fish.

In conclusion, fish spermatogenesis may be inhibited by using antiandrogens such as cyproterone acetate and oxymetholone added to the diet, provided that the treatment is started before spermatogenesis is initiated. Cyproterone acetate seems more suitable than oxymetholone because the fish do not lose weight during the treatment. The effects are possibly reversible since germ cells are still present in the testis after more than 150 days of treatment; however, this point remains to be demonstrated because the structure of the testes was considerably modified. It would also be interesting to see if the treatment is necessary throughout the whole period of spermatogenesis rather than just the start. In addition, this would indicate if the antiandrogens can be withdrawn for some weeks or months from marketing to allow flesh residues to disappear without a corresponding testicular recrudescence. This is not likely to happen in the winter where the environmental conditions are not appropriate for recrudescence of spermatogenesis but this may be possible in summer and early autumn.

Because of this possibility of regeneration these drugs could not be used for sterilizing the gonads definitively in foreign species released in the wild. Cyproterone acetate might be useful in intensive fish farming but since growth rate was somewhat lower than in the controls, extensive experimentation is necessary before definitive conclusions can be reached on the influence on growth.

\section{ACKNOWLEDGMENTS}

We thank Schering, Syntex, and Techni-pharma for supplying us with the drugs, Dr. Breton for furnishing the t-GTH and the antibodies, and Ms. Alice Daifuku 
for editing the English manuscript. We are also indebted to Ms. Reinaud and Mr. Richard who helped with the radioimmunoassay and the animal care. This work was supported by the Institut National de la Recherche Agronomique and the Centre National pour l'Exploitation des Océans.

\section{REFERENCES}

Back, D. J., Glovert, T. D., Shenton, J. C., and Boyd, G. P. (1977). Some effects of cyproterone and cyproterone acetate on the reproductive physiology of the male rat. J. Reprod. Fert. 49, 237-243.

Billard, R., Richard, M., and Breton B. (1977). Stimulation of gonadotropin secretion after castration in rainbow trout. Gen. Comp. Endocrinol. 33, $163-165$.

Billard, R., Breton, B., and Richard, M. (1981). On the inhibitory effects of some steroids on spermatogenesis in adult rainbow trout. Canad.J. Zool. 59, 1479-1487.

Breton, B., Kann, G., Burzawa-Gerard, E., and Billard, R. (1971). Dosage radioimmunologique d'une hormone gonadotrope de carpe Cyprinus carpio L. C. R. Acad. Sci. 272, 1515-1517.

Chevassus, B., Blanc, J. M., and Chourrout, D. (1979). Le contróle de la reproduction chez les poissons. II. Reproduction différée et stérilité. Bull. Fr. Pisc. 274, 33-46.

De Rooij, D. G., and Kramer, M. F. (1970). The effect of three alkylating agents on the seminiferous epithelium of rodents. I. Depletory effects. Verchows Arch. Abt. B. Zellpath. 4, 267-275.

Fox, B. W., Jackson, H., Craig, A. W., and Glover, T. D. (1963). Effects of alkylating agents on spermatogenesis in the rabbit. J. Reprod. Fert. 5, $13-22$.

Gillet, J., and Laporte, P. (1973). Action du busulfan et de FSH sur le tube séminifère du rat: effects morphologiques et cellulaires. Arch. Anat. Microsc. Morphol. Exp. 62, 385-398.

Gilmore, D. P. (1973). The synergistic action of antifertility compounds in the male rat. Biol. $R \boldsymbol{e}$ prod. 9, 544-548.

Goetz, F. W., Donaldson, E. M., Hunter, G. A., and Dye, H. M. (1979). Effects of oestradiol $17 \beta$ and $17 \alpha$-methyltestosterone on gonadal differentiation in the coho salmon, Oncorhynchus kisutch. Aquaculture 17, 267-278.

Hamaguchi, S. (1978). The inhibitory effects of cyproterone acetate on the male secondary sex characters of the medaka, Oryzias latipes. Annot. Zool. Japon. 51, 65-69.

Hewsworth, B. N., and Jackson, H. (1962). Effect of busulfan on the foetal gonad, Nature (London) 195, 816.

Jackson, M., Fox, B. W., and Craig, A. W. (1959). The effect of alkylating agents on male rat fertility. Brit. J. Pharmacol. 14, 149-157.

Jalabert, B., Billard, R., and Chevassus, B. (1975). Preliminary experiments on sex control in trout: Production of sterile fishes and simultaneous self-fertilizable hermaphrodites. Ann. Biol. Anim. Bioch. Biophys. 15, 19-28.

Johnstone, R., Simpson, T. M., and Youngson, H. F. (1978). Sex reversal in salmonid culture. Aquaculture 13, 115-134.

Morse, H. C., Leach, D. R., Rowley, M. J., and Heller, C. G. (1973). Effect of cyproterone acetate on sperm concentration, seminal fluid volume, testicular cytology and levels of plasma and urinary ICSH, FSH and testosterone in normal men. $J$. Reprod. Fert. 32, 365-378.

Murphy, T. M. (1980). The effect of methallibure and cyproterone acetate on the gonadotrophic cells, plasma androgen levels and testes of precocious 1 male Atlantic salmon parr Salmo salar L. $J$. Fish Biol. 17, 673-680.

Partington, M., Fox, B. W., and Jackson, H. (1964). Comparative action of some methane sulphonic esters on the cell population of the rat testis. Exp. Cell. Res. 33, 78-98.

Rouse, E. F., Coppenger, C. J., and Bames, P. R. (1977). The effect of an androgen inhibitor on behaviour and testicular morphology in the stickleback Gasterosteus aculeatus. Horm. Behav. 9, 8-18.

Schreck, C. F. (1973). Uptake of ${ }^{3} \mathrm{H}$-testosterone and influence of an antiandrogen in tissues of rainbow trout (Salmo gairdneri). Gen. Comp. Endocrinol. 21, 60-68.

Steinbeck, M., Mehring, M., and Neumann, F. (1971). Comparison of the effects of cyproterone, cyproterone acetate and estradiol on testicular function, accessory gland and fertility in a long term study on rats. J. Reprod. Fert. 26, 65-76.

Viguier-Martinez, M. C. (1976), Plasma LH response to LH-RH injection in immature intact, castrated and cyproterone treated male rats. $J$. Reprod. Fert. 48, 195-197.

Yamazaki, F. 1976. Application of hormones in fish culture. J. Fish Res. Board Canad. 33, 948-958. 